\title{
Reclassification of strain CCM 132, previously classified as Kocuria varians, as Kocuria carniphila
} sp. nov.

Correspondence Ludmila Tvrzová lida@sci.muni.cz

\author{
Ludmila Tvrzová, ${ }^{1}$ Peter Schumann, ${ }^{2}$ Ivo Sedláček, ${ }^{3}$ Zdena Páčová, ${ }^{3}$ \\ Cathrin Spröer, ${ }^{2}$ Susanne Verbarg ${ }^{2}$ and Reiner M. Kroppenstedt ${ }^{2}$ \\ ${ }^{1}$ Department of Microbiology, Faculty of Science, Masaryk University Brno, Tvrdého 14, \\ 60200 Brno, Czech Republic
}
${ }^{2} \mathrm{DSMZ}$ - Deutsche Sammlung von Mikroorganismen und Zellkulturen, Mascheroder Weg $1 \mathrm{~b}$, D-38124 Braunschweig, Germany
${ }^{3} \mathrm{CCM}$ - Czech Collection of Microorganisms, Masaryk University Brno, Tvrdého 14, 60200 Brno, Czech Republic

Strain CCM 132 was deposited in the CCM as 'Micrococcus lactis' in 1959. This strain, isolated from meat (Kocur \& Martinec, 1962), was extensively studied in the 1960s and 1970s (Boháček et al., 1967; Jeffries et al., 1969; Kocur et al., 1971) and was classified as Micrococcus varians. The genus Kocuria was established by Stackebrandt et al. (1995) by taxonomic dissection of the genus Micrococcus and consequently CCM 132 was reclassified as Kocuria varians. Because the phenotypic features of strain CCM 132 differed from those of the $K$. varians species description, strain CCM 132 was subjected to a detailed taxonomic study.

Strain CCM 132 was cultivated aerobically on tryptone soya medium (Oxoid) at $28^{\circ} \mathrm{C}$. Genomic DNA extraction, PCR-mediated amplification of the 16S rRNA gene and purification of PCR products were carried out as described previously (Rainey et al., 1996). Purified PCR products were sequenced using the CEQ DTCS Quick Start kit (Beckman Coulter), as directed in the manufacturer's protocol. The CEQ 8000 Genetic Analysis System was used for electrophoresis of the sequence reaction products.

The ae2 editor (Maidak et al., 1999) was used to align the 16S rRNA gene sequence of CCM 132 against those

Published online ahead of print on 8 October 2004 as DOI 10.1099/ ijs.0.63304-0.

The GenBank/EMBL/DDBJ accession number for the 16S rRNA gene sequence of strain CCM $132^{\top}$ is AJ622907.

A phylogenetic tree showing the placement of strain $\mathrm{CCM} 132^{\top}$ in the genus Kocuria is available as supplementary material in IJSEM Online. of representatives of the main bacterial lineages available from the public databases. A phylogenetic tree was constructed, the topology of which was evaluated by bootstrap resampling (Felsenstein, 1993) with 1000 replicates. An almost-complete 16S rRNA gene sequence, of 1515 nucleotides, was determined for strain CCM 132 ranging from position $15\left(5^{\prime}\right)$ to $1536\left(3^{\prime}\right)$ (Escherichia coli numbering; Brosius et al., 1978). Phylogenetic analyses based on a dataset consisting of 1406 unambiguous nucleotides between positions 42 and 1458 showed that strain CCM 132 represented a distinct lineage within the radiation of the genus Kocuria, in a tight phylogenetic group together with Kocuria rhizophila and K. varians (bootstrap resampling value, $99 \%$ ). The highest binary $16 \mathrm{~S}$ rRNA similarity values were found with $K$. rhizophila DSM $11926^{\mathrm{T}}$ (97·4\%) and $K$. varians DSM $20033^{\mathrm{T}}(96.9 \%)$. The phylogenetic tree showing the placement of CCM 132 in the genus Kocuria is available as supplementary material in IJSEM Online.

DNA for DNA-DNA hybridization was isolated using a French pressure cell (Thermo Spectronic) and was purified by chromatography on hydroxyapatite as described by Cashion et al. (1977). DNA-DNA hybridization was carried out as described by De Ley et al. (1970), with the modifications described by Huss et al. (1983) and Escara \& Hutton (1980), using a model 2600 spectrophotometer equipped with a model 2527-R thermoprogrammer and plotter (Gilford Instrument Laboratories). Renaturation rates were computed with the TRANSFER.BAS program of Jahnke (1992). The DNA-DNA reassociation value between strain CCM 132 and its closest phylogenetic neighbour, K. rhizophila 
DSM $11926^{\mathrm{T}}$, was $36 \cdot 2 \%$, clearly below the $70 \%$ value considered to be the threshold for the delineation of genomic species (Wayne et al., 1987).

A new species of the genus Kocuria, Kocuria marina, has been described recently (Kim et al., 2004). A comparison of the 16S rRNA gene sequences of the type strain of K. marina and strain CCM 132 revealed $97.9 \%$ similarity between these two taxa. The type strains were subjected to DNADNA hybridization. The DNA-DNA reassociation value between strain CCM 132 and K. marina DSM $16420^{\mathrm{T}}$ was $28.0 \%$ (repetition, $26.4 \%$ ), indicating that the strains belong to distinct genomic species. Moreover, CCM 132 differs from K. marina DSM $16420^{\mathrm{T}}$ (Kim et al., 2004) by negative hydrolysis of gelatin and urea and by positive production of acid from lactose and glucose.

The affiliation of strain CCM 132 to the genus Kocuria was confirmed by chemotaxonomic features that are characteristic of the genus Kocuria (Stackebrandt et al., 1995). The peptidoglycan structure was determined by using hydrolysates of purified cell walls according to Schleifer (1985). The amino acids and peptides were separated by twodimensional ascending TLC on cellulose plates with the solvent systems of Schleifer \& Kandler (1972). The molar ratio of the amino acids was determined by GC as described by MacKenzie (1987). Menaquinones were extracted according to Collins et al. (1977) and analysed by using HPLC (Groth et al., 1996). Cells for cellular fatty acid analysis were harvested from $24 \mathrm{~h}$ cultures grown at $28^{\circ} \mathrm{C}$ on tryptone soya medium. Fatty acids were extracted and analysed following the instructions of the Microbial Identification System operating manual (MIDI, 1999). The peptidoglycan of strain CCM 132 contained lysine, glutamic acid and alanine in a molar ratio of about $0 \cdot 8: 1 \cdot 0: 5 \cdot 0$, respectively. Based on these data and on the occurrence of characteristic peptides in the partial hydrolysate of the peptidoglycan (data not shown), the peptidoglycan type is consistent with the type Lys- $\mathrm{Ala}_{3}$, variation A3 $\alpha$ (Schleifer \& Kandler, 1972), A11.6 according to the DSMZ Catalogue of strains (DSMZ, 2001). The interpeptide bridge of the peptidoglycan of strain CCM 132 containing three alanine residues (type A11.6) was also detected in the type strains of Kocuria polaris (Reddy et al., 2003), Kocuria palustris and K. rhizophila (Kovács et al., 1999), and in Kocuria rosea DSM 11630 (Schleifer \& Kandler, 1972). However, the type strains of $K$. rosea and $K$. varians, as well as the K. varians strains DSM 20319 and DSM 20320, were reported to contain four alanine residues in the interpeptide bridge (type A11.7; Schleifer \& Kandler, 1970, 1972; DSMZ, 2001). The menaquinone pattern of strain CCM 132 , with MK- $7\left(\mathrm{H}_{2}\right):$ MK- $8\left(\mathrm{H}_{2}\right)$ : MK- $6\left(\mathrm{H}_{2}\right)$, peak area ratio $88: 3: 4$, corresponds to that of $K$. varians DSM $20033^{\mathrm{T}}$ in its high content of MK-7 $\left(\mathrm{H}_{2}\right)$ (Stackebrandt et al., 1995), but differentiates the isolate from the closely related species K. rhizophila DSM $11926^{\mathrm{T}}$, which also contains significant amounts of MK- $8\left(\mathrm{H}_{2}\right)$; MK-7 $\left(\mathrm{H}_{2}\right):$ MK- $8\left(\mathrm{H}_{2}\right):$ MK6 $\left(\mathrm{H}_{2}\right):$ MK-9 $\left(\mathrm{H}_{2}\right), 51: 39: 4: 1$ (Kovács et al., 1999). The cellular fatty acids content of strain CCM 132 was as follows. The major fatty acids were anteiso- $\mathrm{C}_{15: 0}(68 \cdot 0 \%)$ and anteiso- $\mathrm{C}_{17: 0},(12 \cdot 8 \%)$. anteiso- $\mathrm{C}_{13: 0}(0 \cdot 2 \%)$, iso$\mathrm{C}_{14: 0}(2 \cdot 3 \%), \mathrm{C}_{14: 0}(1 \cdot 8)$, iso- $\mathrm{C}_{15: 0}(3 \cdot 8 \%)$, iso- $\mathrm{C}_{16: 0}$ $(3 \cdot 5 \%), \mathrm{C}_{16: 0}(5 \cdot 0 \%)$ and iso- $\mathrm{C}_{17: 0}(0 \cdot 6 \%)$ occurred in minor amounts. The fatty acid profile was in agreement with data reported for other Kocuria species (Stackebrandt et al., 1995; Kovács et al., 1999; Reddy et al., 2003). The fatty acid methyl ester profile of strain CCM 132 differed from that of $K$. rhizophila DSM $11926^{\mathrm{T}}$ by a higher amount of anteiso- $\mathrm{C}_{15: 0}$ and lower amounts of iso- $\mathrm{C}_{15: 0}$ and anteiso$\mathrm{C}_{17: 0}$ (Kovács et al., 1999).

The G+C content of the DNA of strain CCM 132 was $71 \mathrm{~mol} \%$ (Boháček et al., 1967), which is in agreement with the description of the genus Kocuria (Stackebrandt et al., 1995).

For the comparative phenotypic studies, strain CCM 132 and type strains of Kocuria species [K. rhizophila DSM $11926^{\mathrm{T}}\left(=\mathrm{CCM} 4950^{\mathrm{T}}\right)$, K. varians DSM $20033^{\mathrm{T}}(=\mathrm{CCM}$ $\left.884^{\mathrm{T}}\right), K$. palustris DSM $11925^{\mathrm{T}}\left(=\mathrm{CCM} 4949^{\mathrm{T}}\right)$, K. polaris DSM $14382^{\mathrm{T}}, K$. rosea DSM $20447^{\mathrm{T}}\left(=\mathrm{CCM} 679^{\mathrm{T}}\right)$ and $K$. kristinae DSM $20032^{\mathrm{T}}\left(=\mathrm{CCM} 2690^{\mathrm{T}}\right)$ ] were routinely cultivated on tryptone soya medium (Oxoid) at $28^{\circ} \mathrm{C}$. Standardized methods described previously (Barrow \& Feltham, 1993) and API ID 32 STAPH, API STAPH and Biolog GP MicroPlate systems were used for phenotypic characterization of strain CCM 132. The commercial kits were applied according to the manufacturer's instructions. The colonies of strain CCM 132 grown aerobically on nutrient agar were yellow-coloured, circular, convex and opaque. Strain CCM 132 can be easily differentiated from all Kocuria species by physiological characteristics (Table 1). Additional phenotypic characteristics are given below in the species description.

Based on the results of phylogenetic analysis and its chemotaxonomic and physiological properties, it is proposed to reclassify strain CCM 132 (=DSM 16004) as a novel Kocuria species, Kocuria carniphila sp. nov.

\section{Description of Kocuria carniphila sp. nov.}

Kocuria carniphila (car.ni'phi.la. L. n. caro gen. carnis meat; Gr. fem. adj. philos loving; N.L. fem. adj. carniphila meat-loving).

Cells are coccoid, $1-1 \cdot 5 \mu \mathrm{m}$ in diameter, occurring in pairs and tetrads, Gram-positive, non-motile, non-acid-fast and non-spore-forming. Colonies are yellow, circular, convex and opaque. Obligately aerobic. Good growth at $28-37^{\circ} \mathrm{C}$. Growth over $\mathrm{pH}$ range $7 \cdot 0-9 \cdot 1$. Very weak growth in the presence of $10 \%(\mathrm{w} / \mathrm{v}) \mathrm{NaCl}$. Catalase-, $\beta$-galactosidaseand $\beta$-glucuronidase-positive. Negative for oxidase, Voges-Proskauer test, arginine dihydrolase, ornithine decarboxylase, urease, phosphatase and pyrrolidonyl arylamidase. Nitrate is reduced to nitrite. Nitrite is not reduced. Starch, gelatin, Tween 80 and aesculin are not hydrolysed. 
Table 1. Differentiating characteristics of Kocuria carniphila CCM $132^{\top}$ and type strains of Kocuria species

Strains: 1 , K. carniphila sp. nov. CCM $132^{\mathrm{T}} ; 2$, K. rhizophila DSM $11926^{\mathrm{T}}$; 3, K. varians DSM $20033^{\mathrm{T}}$; 4, K. palustris DSM $11925^{\mathrm{T}}$; 5 , K. polaris DSM $14382^{\mathrm{T}} ; 6$, K. rosea DSM $20447^{\mathrm{T}} ; 7$, K. kristinae DSM $20032^{\mathrm{T}}$. + , Positive reaction; - , negative reaction; $\mathrm{W}$, weak reaction.

\begin{tabular}{|c|c|c|c|c|c|c|c|}
\hline Characteristic & 1 & 2 & 3 & 4 & 5 & 6 & 7 \\
\hline Urease & - & - & + & + & - & - & - \\
\hline$\beta$-Galactosidase & + & - & + & + & $+^{*}$ & - & - \\
\hline$\beta$-Glucuronidase & + & - & - & - & - & - & - \\
\hline Nitrate reduction & + & - & + & + & + & + & - \\
\hline \multicolumn{8}{|l|}{ Hydrolysis of: } \\
\hline Tween 80 & - & + & - & - & + & - & - \\
\hline Gelatin & - & + & $\mathrm{W}$ & - & $+^{*}$ & - & $\mathrm{W}$ \\
\hline \multicolumn{8}{|l|}{ Acidification of: } \\
\hline Mannose & - & $-*$ & - & - & $\mathrm{W}$ & - & + \\
\hline Lactose & + & - & $+^{*}$ & + & $\mathrm{W}$ & - & - \\
\hline Trehalose & - & - & - & - & $\mathrm{W}$ & - & + \\
\hline Sucrose & $\mathrm{W}$ & $-*$ & - & + & + & - & + \\
\hline \multicolumn{8}{|l|}{ Utilization of: } \\
\hline$N$-Acetyl-D-mannosamine & + & - & - & - & - & - & - \\
\hline D-Galacturonic acid & + & - & - & - & - & - & - \\
\hline Methyl $\alpha$-D-galactoside & + & - & - & - & - & - & - \\
\hline 3-Methyl glucose & + & - & $\mathrm{W}$ & - & - & - & + \\
\hline$\beta$-Hydroxybutyric acid & + & - & + & - & + & - & - \\
\hline L-Malic acid & - & + & + & - & + & + & + \\
\hline$N$-Acetylglutamic acid & + & - & + & - & - & - & - \\
\hline Uridine & - & + & + & + & - & $\mathrm{W}$ & - \\
\hline Glucose 6-phosphate & + & - & + & - & - & $\mathrm{W}$ & - \\
\hline
\end{tabular}

${ }^{*}$ Reaction different from data published previously (Stackebrandt et al., 1995; Kovács et al., 1999; Reddy et al., 2003).

Acidification of glucose, fructose and lactose is positive. Weak acid production from maltose and sucrose. Acid production is negative from mannose, raffinose, trehalose, mannitol, xylitol, melibiose, xylose, turanose, ribose, cellobiose, methyl $\alpha$-D-glucopyranoside, $N$-acetylglucosamine and arabinose. The following compounds are utilized: dextrin, Tween 40, Tween 80, $N$-acetyl-D-glucosamine, $\mathrm{N}$-acetyl-D-mannosamine, amygdalin, D-fructose, L-fucose, D-galactose, D-galacturonic acid, gentiobiose, D-gluconic acid, $\alpha$-D-glucose, myo-inositol, maltotriose, D-mannitol, D-mannose, D-melibiose, methyl $\alpha$-D-galactoside, methyl $\beta$-D-galactoside, 3-methyl glucose, D-psicose, D-ribose, sucrose, acetic acid, $\alpha$-hydroxybutyric acid, $\beta$-hydroxybutyric acid, $\gamma$-hydroxybutyric acid, $p$-hydroxyphenylacetic acid, $\alpha$-ketoglutaric acid, $\beta$-ketovaleric acid, L-lactic acid, mono-methyl succinate, propionic acid, pyruvic acid, succinic acid, $N$-acetyl-glutamic acid, L-glutamic acid, Lpyroglutamic acid, glycerol, thymidine $5^{\prime}$-monophosphate and glucose 6 -phosphate. $\alpha$-Cyclodextrin, $\beta$-cyclodextrin, $\mathrm{D}$-arabitol, arbutin, D-galactose, lactulose, D-melezitose, methyl $\alpha$-D-glucoside, methyl $\beta$-D-glucoside, methyl
$\alpha$-D-mannoside, palatinose, D-raffinose, salicin, sedoheptulosan, D-tagatose, xylitol, lactamide, D-lactic acid methyl ester, D-malic acid, L-malic acid, alaninamide, D-alanine, L-alanine, L-alanyl glycine, glycyl-L-glutamic acid, putrescine, inosine, uridine, adenosine $5^{\prime}$-monophosphate and uridine $5^{\prime}$-monophosphate can not be utilized. The cell wall diamino acid is lysine. The peptidoglycan type is Lys-Ala (variation $\mathrm{A} 3 \alpha$ ). The major menaquinone is $\mathrm{MK}-7\left(\mathrm{H}_{2}\right)$. The cellular fatty acid pattern is dominated by anteiso- $\mathrm{C}_{15: 0}$. The $\mathrm{G}+\mathrm{C}$ content is $71 \mathrm{~mol} \%$.

The type strain is CCM $132^{\mathrm{T}}\left(=\mathrm{DSM} 16004^{\mathrm{T}}\right.$ ), which was isolated from meat.

\section{Note added in proof}

A new species of the genus Kocuria, K. marina, was described as this report was being prepared for press (Kim et al., 2004). Consequently, details of a comparison of the type strain of that species, DSM $16420^{\mathrm{T}}$, with K. carniphila CCM $132^{\mathrm{T}}$ have been added to the text.

\section{Acknowledgements}

We are grateful to H. G. Trüper, University of Bonn, Germany, for his help with the Latin construction of the species epithet. We also thank A. Vester, I. Kramer, G. Pötter and A. Frühling (DSMZ) for excellent technical assistance.

\section{References}

Barrow, G. I. \& Feltham, A. K. A. (editors) (1993). Cowan and Steel's Manual for Identification of Medical Bacteria, 3rd edn. Cambridge: Cambridge University Press.

Boháček, J., Kocur, M. \& Martinec, T. (1967). DNA base composition and taxonomy of some micrococci. J Gen Microbiol 46, 369-376.

Brosius, J., Palmer, M. L., Kennedy, P. J. \& Noller, H. F. (1978). Complete nucleotide sequence of a $16 \mathrm{~S}$ ribosomal RNA gene from Escherichia coli. Proc Natl Acad Sci U S A 75, 4801-4805.

Cashion, P., Holder-Franklin, M. A., McCully, J. \& Franklin, M. (1977). A rapid method for the base ratio determination of bacterial DNA. Anal Biochem 81, 461-466.

Collins, M. D., Pirouz, T., Goodfellow, M. \& Minnikin, D. E. (1977). Distribution of menaquinones in actinomycetes and corynebacteria. J Gen Microbiol 100, 221-230.

De Ley, J., Cattoir, H. \& Reynaerts, A. (1970). The quantitative measurement of DNA hybridization from renaturation rates. Eur J Biochem 12, 133-142.

DSMZ (2001). Catalogue of Strains, 7th edn. Braunschweig: DSMZ. Escara, J. F. \& Hutton, J. R. (1980). Thermal stability and renaturation of DNA in dimethyl sulfoxide solutions: acceleration of the renaturation rate. Biopolymers 19, 1315-1327.

Felsenstein, J. (1993). PHYLIP (phylogeny inference package), version 3.5.1. Department of Genetics, University of Washington, Seattle, USA.

Groth, I., Schumann, P., Weiss, N., Martin, K. \& Rainey, F. A. (1996). Agrococcus jenensis gen. nov., sp. nov., a new genus of actinomycetes with diaminobutyric acid in the cell wall. Int J Syst Bacteriol 46, 234-239. 
Huss, V. A. R., Festl, H. \& Schleifer, K. H. (1983). Studies on the spectrophotometric determination of DNA hybridization from renaturation rates. Syst Appl Microbiol 4, 184-192.

Jahnke, K. D. (1992). Basic computer program for evaluation of spectroscopic DNA renaturation data from GILFORD System 2600 spectrometer on a PC/XT/AT type personal computer. J Microbiol Methods 15, 61-73.

Jeffries, L., Cawthorne, M. A., Harris, M., Cook, B. \& Diplock, A. T. (1969). Menaquinone determination in the taxonomy of Micrococcaceae. J Gen Microbiol 54, 365-380.

Kim, S. B., Nedashkovskaya, O. I., Mikhailov, V. V., Han, S. K., Kim, K.-O., Rhee, M.-S. \& Bae, K. S. (2004). Kocuria marina sp. nov., a novel actinobacterium isolated from marine sediment. Int J Syst Evol Microbiol 54, 1617-1620

Kocur, M. \& Martinec, T. (1962). Taxonomic study of the genus Micrococcus. Fac Sci Natur Univ Purkinianae Brun 3, 3-114 (in Czech).

Kocur, M., Bergan, T. \& Mortensen, N. (1971). DNA base composition of Gram-positive cocci. J Gen Microbiol 69, 167-183.

Kovács, G., Burghardt, J., Pradella, S., Schumann, P., Stackebrandt, E. \& Marialigetti, K. (1999). Kocuria palustris sp. nov. and Kocuria rhizophila sp. nov., isolated from the rhizoplane of the narrow-leaved cattail (Typha angustifolia). Int J Syst Bacteriol 49, 167-173.

MacKenzie, S. L. (1987). Gas chromatographic analysis of amino acids as the $N$-heptafluorobutyryl isobutyl esters. J Assoc Off Anal Chem 70, 151-160.

Maidak, B. L., Cole, J. R., Parker, C. T., Jr \& 11 other authors (1999). A new version of the RDP (Ribosomal Database Project). Nucleic Acids Res 27, 171-173.
MIDI (1999). Sherlock Microbial Identification System, Operating Manual, version 3.0. Newark, DE: MIDI Inc.

Rainey, F. A., Ward-Rainey, N., Kroppenstedt, R. M. \& Stackebrandt, E. (1996). The genus Nocardiopsis represents a phylogenetically coherent taxon and a distinct actinomycete lineage: proposal of Nocardiopsaceae fam. nov. Int J Syst Bacteriol 46, 1088-1092.

Reddy, G. S. N., Prakash, J. S. S., Prabahar, V., Matsumoto, G. I., Stackebrandt, E. \& Shivaji, S. (2003). Kocuria polaris sp. nov., an orange-pigmented psychrophilic bacterium isolated from an Antarctic cyanobacterial mat sample. Int J Syst Bacteriol 53, 183-187.

Schleifer, K. H. (1985). Analysis of the chemical composition and primary structure of murein. Methods Microbiol 18, 123-156.

Schleifer, K. H. \& Kandler, O. (1970). Amino acid sequence of the murein of Planococcus and other Micrococcaceae. J Bacteriol 103, 387-392.

Schleifer, K. H. \& Kandler, O. (1972). Peptidoglycan types of bacterial cell walls and their taxonomic implications. Bacteriol Rev 36, 407-477.

Stackebrandt, E., Koch, C., Gvozdiak, O. \& Schumann, P. (1995). Taxonomic dissection of the genus Micrococcus: Kocuria gen. nov., Nesterenkonia gen. nov., Kytococcus gen. nov., Dermacoccus gen. nov., and Micrococcus Cohn 1872 gen. emend. Int J Syst Bacteriol 45, 682-692.

Wayne, L. G., Brenner, D. J., Colwell, R. R. \& 9 other authors (1987). International Committee on Systematic Bacteriology. Report of the ad hoc committee on reconciliation of approaches to bacterial systematics. Int J Syst Bacteriol 37, 463-464. 